\title{
Metabolic clearance rate, production rate, and source of progesterone in donkeys with fetuses of different genotypes
}

\author{
E. L. Sheldrick, P. J. Wright, W. R. Allen* and R. B. Heap \\ Department of Physiology and *Animal Research Station, \\ A.R.C. Institute of Animal Physiology, Babraham, Cambridge CB2 4AT, U.K.
}

Fetal genotype has a pronounced influence upon progestagen and gonadotrophin (PMSG) concentrations in the peripheral blood of mares and donkeys during the first half of pregnancy. Plasma progestagen and PMSG concentrations in donkeys carrying hinny ( $\delta$ horse $\times \phi$ donkey) conceptuses are appreciably higher than in donkeys carrying normal donkey conceptuses, or in mares carrying normal horse conceptuses (Allen, 1975). In contrast, PMSG concentrations are low in mares carrying mule ( 0 donkey $\times q$ horse) conceptuses compared with mares carrying normal horse conceptuses (Bielanski, Ewy \& Pigoniowa, 1956; Clegg, Cole, Howard \& Pigon, 1962; Allen, 1969), although progestagen concentrations are unaffected (Allen, 1975).

Peripheral plasma progestagen concentrations as high as $800 \mathrm{ng} / \mathrm{ml}$ have been recorded in donkeys carrying hinny conceptuses (Allen, 1975). Concentrations of this magnitude occur only rarely in species so far investigated during gestation. In guinea-pigs and other hystricomorph rodents, such high progesterone concentrations are associated with a marked decrease in metabolic clearance rate and the production of a plasma protein with a high affinity for progesterone (Heap \& Illingworth, 1974). In contrast, in pregnant women they may arise from a substantial increase in progesterone production rates due to increased placental secretion. The following experiments were carried out to determine whether either of these mechanisms is influenced by fetal genotype in equids.

The metabolic clearance rate(MCR) and production rate(PR) of progesterone were measured in 3 donkeys carrying a normal donkey conceptus, 4 donkeys carrying a hinny conceptus and 1 mare carrying a horse conceptus. The methods used for the infusion of $\left[7 \alpha-{ }^{3} \mathrm{H}\right]$ progesterone, the analysis of blood samples, and the calculation of MCR and PR of progesterone and its conversion to metabolites $\left(\mathrm{C}_{\mathrm{BB}}\right)$ have been described by Bedford, Harrison \& Heap (1972). Validation of the analytical techniques used in tracer kinetic studies showed no metabolism of $1 \mu \mathrm{Ci}\left[7 \alpha-{ }^{3} \mathrm{H}\right]$ progesterone by donkey blood $(10 \mathrm{ml})$ when incubated at $37^{\circ} \mathrm{C}$ for $3 \mathrm{~h} .\left[^{3} \mathrm{H}\right]$ Progesterone concentrations measured in jugular venous blood taken during the continuous infusion of labelled progesterone into the opposite jugular vein reached a steady state $3 \mathrm{~h}$ after the start of the infusion. The mean coefficient of variation of at least 3 samples taken during steady-state conditions was $12.3 \%$ (10 experiments). The concentration of endogenous progesterone in arterial and jugular vein blood was similar in samples taken simultaneously under anaesthesia, implying that head extraction was negligible. Plasma progesterone was determined by radioimmunoassay (Heap, Gwyn, Laing \& Walters, 1973; method A). The antiserum used in these studies, BF 465 No. 6 (kindly supplied by Dr B. J. A. Furr), was raised in a goat immunized against progesterone conjugated to bovine serum albumin through the 11-position. The main cross-reactants tested were progesterone $(100 \%), 11 \alpha$-hydroxypregn-4-ene-3,20-dione $(117.0 \%), 5 \alpha$-pregnane-3,20dione $(35 \cdot 3 \%)$, and $11 \beta$-hydroxypregn-4-ene-3,20-dione $(35.0 \%)$. Progesterone was the major progestagen determined in this study, and the values presented are referred to as progesterone concentrations. Progesterone was also measured in one experiment in a donkey carrying a hinny fetus on Day 64 of pregnancy (ovulation = Day 0 ) by competitive protein binding (Allen \& Rossdale, 1973).

The MCR of progesterone from blood was similar in donkeys carrying a donkey or hinny fetus (Table 1); the mean ( \pm S.E.M.) MCR in 10 experiments on 7 donkeys and 1 mare was $12.34 \pm 1.91$ $1 / \mathrm{min}$. These results suggest that the high plasma progesterone concentration in donkeys carrying a hinny conceptus is not associated with a substantial increase in any specific progesterone-binding protein. The binding of progesterone by plasma proteins was further examined by using the technique described by Illingworth \& Deanesly (1972). [ $\left.{ }^{3} \mathrm{H}\right]$ Progesterone was added to plasma and 
Table 1. The metabolic clearance rate (MCR) from blood and the production rate (PR) of progesterone in donkeys carrying a donkey or a hinny conceptus (mean \pm S.E.M.)

\begin{tabular}{|c|c|c|c|c|c|c|}
\hline \multirow{2}{*}{$\begin{array}{c}\text { Days of } \\
\text { pregnancy (ovulation } \\
=\text { Day } 0 \text { ) }\end{array}$} & \multirow{2}{*}{$\begin{array}{l}\text { No. of } \\
\text { experiments } \\
\text { (animals) }\end{array}$} & \multirow{2}{*}{$\begin{array}{c}\text { Blood } \\
\text { progesterone } \\
\text { conc. (ng/ml) }\end{array}$} & \multicolumn{2}{|c|}{ MCR } & \multicolumn{2}{|c|}{ PR } \\
\hline & & & $1 / \mathrm{min}$ & $1 / \min / \mathrm{kg}^{0.75}$ & $\mu \mathrm{g} / \mathrm{min}$ & $\mu \mathrm{g} / \min / \mathrm{kg}^{0.75}$ \\
\hline \multicolumn{7}{|l|}{ Normal conceptus } \\
\hline 28,35 & $2(2)$ & $2 \cdot 6,17 \cdot 1$ & $9 \cdot 39,16 \cdot 48$ & $0.18,0.32$ & 24,281 & $0.47,5.39$ \\
\hline$* 52,56,59$ & $3(3)$ & $10 \cdot 8 \pm 2 \cdot 0$ & $17.45 \pm 2.76$ & $0.32 \pm 0.06$ & $196 \pm 63$ & $3.71 \pm 1.32$ \\
\hline Overall mean* & $5(4)$ & $10 \cdot 4 \pm 2 \cdot 6$ & $15 \cdot 65 \pm 2 \cdot 19$ & $0.29 \pm 0.04$ & $178 \pm 54$ & $3.40 \pm 1.08$ \\
\hline \multicolumn{7}{|l|}{ Hinny conceptus } \\
\hline 31,34 & $2(2)$ & $5 \cdot 2,7 \cdot 4$ & $8 \cdot 50,10 \cdot 87$ & $0.17,0.22$ & 62,56 & $1 \cdot 22,1 \cdot 14$ \\
\hline $60,60,70$ & $3(3)$ & $189 \cdot 3 \pm 46 \cdot 7$ & $10 \cdot 54 \pm 5.44$ & $0.21 \pm 0.11$ & $1513 \pm 515$ & $29.57 \pm 10.06$ \\
\hline Overall mean & $5(4)$ & $116 \cdot 1 \pm 51 \cdot 6$ & $10.20 \pm 3.01$ & $0.20 \pm 0.13$ & $932 \pm 454$ & $18.21 \pm 8.87$ \\
\hline
\end{tabular}

* Includes a mare carrying a horse conceptus: progesterone concentration, $7 \cdot 35 \mathrm{ng} / \mathrm{ml} ; \mathrm{MCR}, 17 \cdot 24 \mathrm{l} / \mathrm{min}, 0 \cdot 27$ $1 / \mathrm{min} / \mathrm{kg}^{0.75} ; \mathrm{PR}, 126 \mu \mathrm{g} / \mathrm{min}, 1.96 \mu \mathrm{g} / \mathrm{min} / \mathrm{kg}^{0.75}$. These data are included in the means because the fetus is of the same genotype as the dam.

extracted with petroleum ether. The amount recovered from plasma taken from either a donkey carrying a hinny conceptus or a donkey carrying a normal donkey conceptus was greater than $95 \%$. This finding confirms the suggestion that the concentration of any specific binding protein was low and that it did not increase in the presence of a hinny conceptus.

The production rate of progesterone in donkeys carrying a normal donkey conceptus at Days 28 and 35 of pregnancy was similar to that found at Days 56 and 59. The marked increases between Days 31-34 and Days 60-70 in donkeys carrying a hinny conceptus were mirrored by comparable increases in plasma progesterone concentrations (Table 1).

Ganjam, Kenney \& Flickinger (1975) have shown that at least two unknown compounds present in the plasma of pregnant mares cross-react in their progesterone radioimmunoassay; these com-
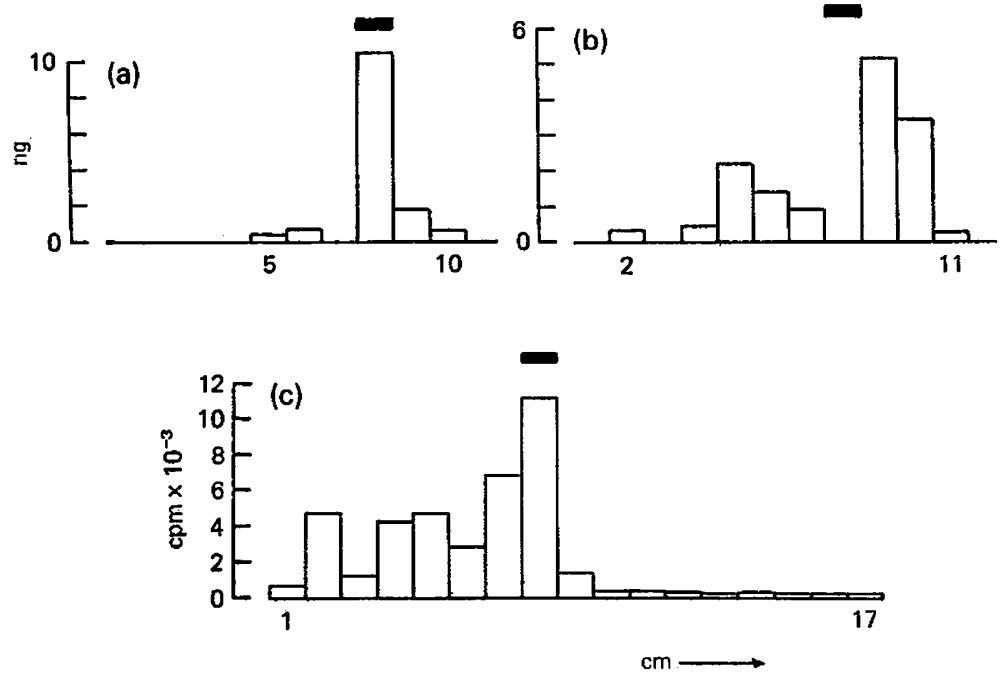

Text-fig. 1. Identification of progesterone and progesterone metabolites in the blood of a donkey carrying a hinny conceptus. Blood was extracted as described in the text, separated by thin-layer chromatography (methylene chloride: diethyl ether, $5: 2 \mathrm{v} / \mathrm{v}$ ) and $1-\mathrm{cm}$ bands eluted. The position of authentic progesterone is marked by the bar. Each fraction was measured by radioimmunoassay and results show that (a) progesterone was the major component in a donkey carrying a hinny conceptus, Day 70 of pregnancy; (b) immunoreactivity in a mare carrying a horse conceptus near term was attributable to compounds other than progesterone and which were not present in (a). (c) At steady state during the infusion of $\left[{ }^{3} \mathrm{H}\right]$ progesterone into a donkey carrying a hinny conceptus at Day 70 of pregnancy, $\left[{ }^{3} \mathrm{H}\right]$ progesterone was metabolized to more polar compounds. 
pounds were not present during the first 5 months of gestation. Holtan, Nett \& Estergreen (1975), however, found two similar and also unidentified compounds that first appeared in plasma between Days 30 and 60 of gestation and increased gradually to Day 300 . The progesterone metabolite, $5 a$-pregnane-3,20-dione, has been subsequently identified in the peripheral circulation of the pregnant mare and its concentration in the first 100 days of gestation was similar to that of progesterone (Atkins, Harms, Sorensen \& Fleeger, 1976). The possibility existed, therefore, that the high progesterone production rates observed in donkeys carrying hinny conceptuses may have resulted from the presence in blood of high concentrations of other cross-reacting compounds. In our experiments there was a low conversion of $\left[{ }^{3} \mathrm{H}\right]$ progesterone to $\left[{ }^{3} \mathrm{H}\right] 20 \alpha$-hydroxy-pregn-4-en-3-one $\left(\mathrm{C}_{\mathrm{BB}}<5 \%\right)$ in a donkey carrying a hinny conceptus at Day 60, although extensive conversion to other polar metabolites, but not to less polar metabolites such as $5 \alpha$ - and $5 \beta$-pregnanedione, did occur (Text-fig. 1c). These polar metabolites were not immunoreactive (Text-fig. 1a).

Further investigations showed that progesterone was the major progestagen in the blood of a donkey carrying a donkey conceptus at Day 56 and in a donkey carrying a hinny conceptus at Day 60 (Text-fig. 1a). This finding contrasts with that obtained for blood taken from two mares near term in which immunoreactivity was attributable mainly to compounds other than progesterone (Text-fig. 1b).

The source of the high rate of progesterone production in donkeys carrying a hinny conceptus was also examined by measuring the concentration of progesterone in the ovarian and uterine veins at laparotomy between Days 57 and 64 (Table 2). In 3 donkeys carrying a hinny conceptus the progesterone concentration in the ovarian vein was high $(4687 \pm 1711 \mathrm{ng} / \mathrm{ml})$ compared with that in the uterine $(258 \pm 90 \mathrm{ng} / \mathrm{ml})$ or jugular $(204 \pm 76 \mathrm{ng} / \mathrm{ml})$ veins. In a donkey carrying a donkey conceptus the mean ovarian vein concentration was only $59 \mathrm{ng}$ progesterone $/ \mathrm{ml}$, compared with a mean value of $264 \mathrm{ng} / \mathrm{ml}$ in the uterine vein and $37 \mathrm{ng} / \mathrm{ml}$ in a jugular vein. The results confirm that the maternal ovaries are a principal source of progesterone in early pregnancy in donkeys carrying a hinny conceptus as suggested by Allen (1975).

Table 2. Plasma progesterone concentrations ( $\mathrm{ng} / \mathrm{ml}$ plasma) in ovarian, uterine and jugular vein of donkeys carrying a donkey or hinny conceptus

\begin{tabular}{lrrrr}
\hline & \multicolumn{5}{c}{ Conceptus } \\
\cline { 2 - 6 } & Donkey & Hinny & Hinny & Hinny \\
Day of gestation (ovulation = Day 0) & 57 & 60 & 62 & 64 \\
\hline Progesterone conc. & & & & \\
Jugular vein & 37 & 138 & 355 & 119 \\
Ovarian vein-pregnant side & 62 & 360 & 8100 & 1938 \\
$\quad$-non-pregnant side & 56 & - & 9160 & 3877 \\
Uterine vein - pregnant side & 390 & 140 & 495 & 129 \\
$\quad$-non-pregnant side & 138 & 98 & 584 & 103 \\
\hline
\end{tabular}

Thus, it has been shown that the unusually high concentration of peripheral plasma progesterone in donkeys carrying a hinny conceptus compared with that in the other equine pregnancies was due to a marked increase in progesterone production rate rather than a decrease in metabolic clearance rate. This influence of fetal genotype on progesterone production rate is associated with a marked stimulation of ovarian function at a time when high concentrations of PMSG are present in maternal blood.

\section{References}

ALLEN, W.R. (1969) Factors influencing pregnant mare serum gonadotrophin production. Nature, Lond. 223, 64-66.

ALLEN, W.R. (1975) The influence of fetal genotypes upon endometrial cup development and PMSG and progestagen production in equids. J. Reprod. Fert., Suppl. 23, 405-413.

Allen, W.R. \& Rossdale, P.D. (1973) A preliminary 
study upon the use of prostaglandins for inducing oestrus in non-cycling Thoroughbred mares. Eq. vet. J. 5, 137-140.

AtkIns, D.T., Harms, P.G., Sorensen, A.M., JR \& FleEger, J.L. (1976) Isolation, identification and quantitation of serum $5 \alpha$-pregnane-3,20-dione and its relationship to progesterone in the pregnant mare. Steroids 28, 867-880.

Bedford, C.A., Harrison, F.A. \& Heap, R.B. (1972) The metabolic clearance rate and production rate of progesterone and the conversion of progesterone to 20a-hydroxypregn-4-en-3-one in the sheep. $J$. Endocr. 55, 105-118.

Bizlanski, W., Ewy, Z., Pigoniowa, H. (1956) Difference in the level of gonadotrophin in the serum of pregnant mares. Proc. 3rd Int. Congr. Anim. Reprod. \& A.I., Cambridge, pp. 110-111.

Clegg, M.T., Cole, H.H., Howard, C.B. \& Pigon, H. (1962) The influence of foetal genotype on equine gonadotrophin secretion. $J$. Endocr. 25, 245248.

Ganjam, V.K., Kenney, R.M. \& Flickinger, G.
(1975) Plasma progesterone in cyclic, pregnant and post-partum mares. J. Reprod. Fert., Suppl. 23, 441-447.

Heap, R.B., Gwyn, M., Laing, J.A. \& Walters, D. E. (1973) Pregnancy diagnosis in cows; changes in milk progesterone concentration during the oestrous cycle and pregnancy measured by a rapid radioimmunoassay. J. agric. Sci., Camb. 81, 151-157.

Heap, R.B. \& Illngworth, D.V. (1974) The maintenance of gestation in the guinea-pig and other hystricomorph rodents: changes in the dynamics of progesterone metabolism and the occurrence of progesterone-binding globulin (PBG). Symp, zool. Soc. Lond. 34, 385-415.

Holtan, D.W., NetT, T.M. \& Estergreen, V.L. (1975) Plasma progestagens in pregnant mares. $J$. Reprod. Fert. Suppl. 23, 419-424.

Illingworth, D.V. \& DEANESLY, R. (1972) Maintenance of pregnancy by synthetic progestagens in pre-implantation ovariectomized guinea-pigs; progesterone binding protein and placental progesterone secretion. J. Endocr. 54, 435-444.

Received 25 March 1977 